Utah State University

DigitalCommons@USU

1982

\title{
Rates of forest floor decomposition and nutrient turnover in aspen, pine, and spruce stands on two soils
}

Donald A. Perala

D.H. Alban

Follow this and additional works at: https://digitalcommons.usu.edu/aspen_bib

Part of the Forest Sciences Commons

\section{Recommended Citation}

Perala, D. A.; Alban, D.H. 1982. Rates of forest floor decomposition and nutrient turnover in aspen, pine, and spruce stands on two soils. Research Paper NC-227. St. Paul, MN: U.S. Dept. of Agriculture, Forest Service, North Central Forest Experiment Station

This Article is brought to you for free and open access by the Aspen Research at DigitalCommons@USU. It has been accepted for inclusion in Aspen Bibliography by an authorized administrator of DigitalCommons@USU. For more information, please contact

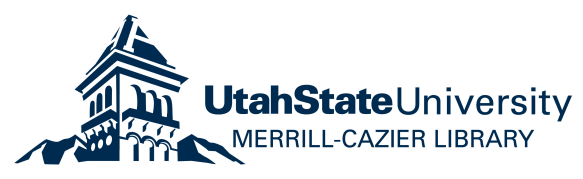




\section{United States \\ Department of Agriculture}

Forest

Service

North Central

Forest Experiment

Station

Research

Paper NC-227

UAS 195

\section{Rates of}

Forest Floor

Decomposition

and Nutrient

Turnover in Aspen,

Pine, and Spruce

Stands on Two

Different Soils

D. A. Perala and D. H. Alban

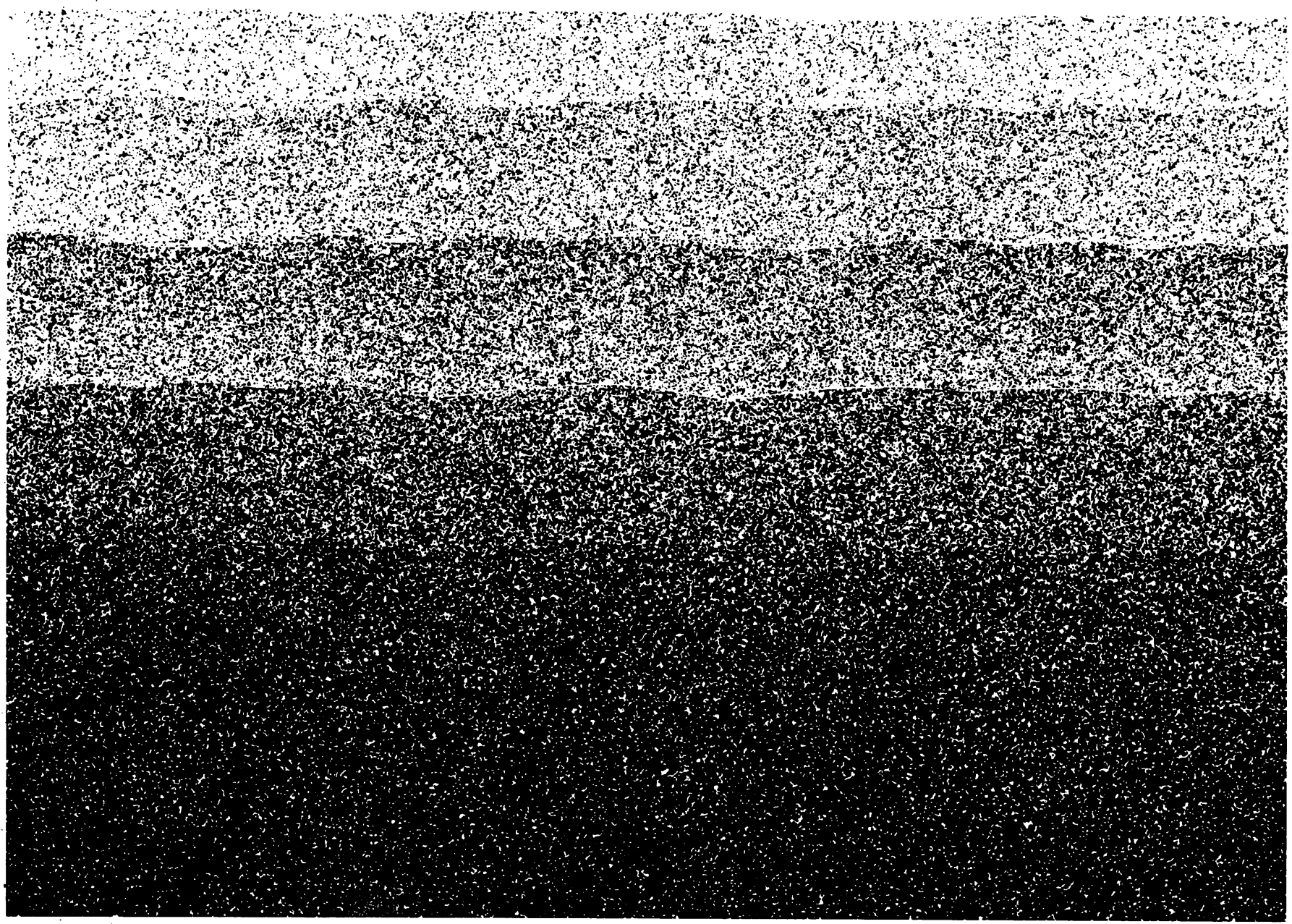


North Central Forest Experiment Station Forest Service-U.S. Department of Agriculture 1992 Folwell Avenue

St. Paul, Minnesota 55108

Manuscript approved for publication September 20, 1982 1982 


\title{
RATES OF FOREST FLOOR DECOMPOSITION AND NUTRIENT TURNOVER IN ASPEN, PINE, AND SPRUCE STANDS ON TWO SOILS
}

\author{
D. A. Perala, Principal Silviculturist, \\ and D. H. Alban, Research Soil Scientist \\ Grand Rapids, Minnesota
}

Tree nutrition - that is, nutrient uptake, retention, and return in litterfall-is fundamentally distinct from the nutrition of annual agronomic crops. The conservation of nutrients in forests by intracycling provides an important portion of annual nutrient demand. In part, it allows good forest growth on soils that would be poor or unsuitable for agriculture.

But before nutrients returned in litterfall can again be available to trees, they must be mineralized. $\mathrm{Nu}$ trients, especially large amounts of $\mathrm{K}$, are made available to some degree through direct leaching. The remaining nutrients are mineralized largely by biological activity-soil micro-organisms, soil animals, and saprophytic plants utilize the organic matter directly as an energy source in their metabolism. Mineral nutrients are eventually released in plant available forms upon the death of the micro-organisms and their predators, or in their waste products. Nitrogen in organic matter is transformed by many biological processes and some becomes available to plants during the nitrogen cycle (Swift et al. 1979).

Since the metabolic rate of soil organisms depends on temperature, moisture, $\mathrm{pH}$, and aeration, rates of forest floor decomposition and nutrient turnover vary with environment. The nature and quality of the litter (ease of breakdown) are also important; these vary among tree species, and particularly between conifers and hardwoods (Swift et al. 1979).

While many researchers have reported decomposition and nutrient turnover rates for individual forest stands (Olson 1963, Cole and Johnson 1978, Krause et al. 1978, Lousier and Parkinson 1976), comparisons among species on the same soil type are rare. Yount (1975) compared white pine and hardwoods on the Coweeta Watershed, but species comparisons replicated on more than one soil are, to our knowledge, nonexistent. In this paper, we will present estimates of forest floor organic matter decomposition and nutrient turnover rates for trembling aspen $(\mathrm{Po}$ pulus tremuloides Michx.), white spruce (Picea glauca (Moench.) Voss), red pine (Pinus resinosa Ait.), and jack pine ( $P$. banksiana Lamb.) growing on two soils of somewhat different site quality.

\section{STUDY AREA}

The study area is located on the Chippewa National Forest in north central Minnesota, U.S.A. (47 $20^{\prime} \mathrm{N}, 94^{\circ} 30^{\prime} \mathrm{W}$ ), in the spruce-fir forest ecoregion (Bailey 1980). The climate is humid warm-summer continental, with cold winters. Annual temperature and precipitation average $4^{\circ} \mathrm{C}$ and $610 \mathrm{~mm}$.

Both soils occur on a gently undulating till plain. One soil is a Warba very fine sandy loam (Glossic Eutroboralf), well drained, with pH of 5-6 above the calcareous $\mathrm{C}$ horizon. The other soil is an unnamed loamy fine sand (Arenic Eutroboralf) underlain at $80 \mathrm{~cm}$ by calcareous loam, well drained, with $\mathrm{pH}$ of 5-6 in the solum.

About 8 ha were cleared on each soil in either 1933 (loam) or in 1934 (sand), and 0.4 ha adjoining plantations were planted in the autumn of 1933 and 1934 with red pine, jack pine, or white spruce. An unplanted control area on the loam developed through suckering into a fully stocked, even-aged aspen stand. No such control area was established on the sand, but an adjacent two-aged (years of origin 1918 and 1926) aspen stand was available for study instead.

Forty-four species in the shrub and herb layers were present on both soils, most commonly Corylus cornuta Marsh., Lonicera canadensis Marsh., Aster 
Table 1.- Stand overstory characteristics

\begin{tabular}{|c|c|c|c|c|c|c|c|c|}
\hline Stand & Soil' & Age & $\begin{array}{c}\text { Trees/ } \\
\text { ha }\end{array}$ & $\begin{array}{l}\text { Mean } \\
\text { height }\end{array}$ & $\begin{array}{c}\text { Mean } \\
\text { d.b.h. } \\
\text { o.b. }\end{array}$ & $\begin{array}{l}\text { Basal } \\
\text { area }\end{array}$ & Biomass & $\begin{array}{l}50 \text { year } \\
\text { site } \\
\text { index }\end{array}$ \\
\hline & & Yrs. & Number & $m$ & $\mathrm{~cm}$ & $m^{2} / h a$ & tha & $m$ \\
\hline Aspen & L & $\begin{array}{l}40 \\
49\end{array}$ & $\begin{array}{l}2,989^{2} \\
1,237^{2}\end{array}$ & $\begin{array}{l}20.3^{3} \\
19.8^{3}\end{array}$ & $\begin{array}{l}18^{3} \\
24^{3}\end{array}$ & $\begin{array}{l}41.7^{2} \\
36.8^{2}\end{array}$ & $\begin{array}{l}205^{2} \\
211^{2}\end{array}$ & $\begin{array}{l}21.9^{3} \\
21.4^{3}\end{array}$ \\
\hline Spruce & $\begin{array}{l}\mathrm{L} \\
\mathrm{S}\end{array}$ & $\begin{array}{l}39 \\
41\end{array}$ & $\begin{array}{l}2,187 \\
2,718\end{array}$ & $\begin{array}{l}14.4 \\
13.7\end{array}$ & $\begin{array}{l}15 \\
14\end{array}$ & $\begin{array}{l}41.1 \\
44.9\end{array}$ & $\begin{array}{l}185 \\
179\end{array}$ & $\begin{array}{l}19.7 \\
18.6\end{array}$ \\
\hline Red pine & L & $\begin{array}{l}39 \\
41\end{array}$ & $\begin{array}{l}1,780 \\
2,364\end{array}$ & $\begin{array}{l}17.6 \\
16.9\end{array}$ & $\begin{array}{l}19 \\
16\end{array}$ & $\begin{array}{l}51.9 \\
49.2\end{array}$ & $\begin{array}{l}243 \\
200\end{array}$ & $\begin{array}{l}20.7 \\
19.6\end{array}$ \\
\hline Jack pine & $\stackrel{L}{S}$ & $\begin{array}{l}39 \\
41\end{array}$ & $\begin{array}{l}1,580 \\
1,236\end{array}$ & $\begin{array}{l}18.4 \\
19.3\end{array}$ & $\begin{array}{l}17 \\
18\end{array}$ & $\begin{array}{l}35.1 \\
30.4\end{array}$ & $\begin{array}{l}175 \\
150\end{array}$ & $\begin{array}{l}21.7 \\
21.6\end{array}$ \\
\hline
\end{tabular}

$1 \mathrm{~L}=$ loam, $\mathrm{S}=$ sand.

Includes middle-story hardwoods.

${ }^{3}$ Aspen only.

macrophyllus L., Maianthemum canadense Desf., and Thalictrum dioicum L. Sixteen species were found exclusively on the sand, including Vaccinium myrtilloides Michx., Rubus strigosus Michx. and Streptopus roseus Michx., and 15 were exclusive to the loam, most notably Acer saccharum Marsh., Tilia americana L., and Actaea rubra (Ait.) Wild. The stand tree characteristics at the time of sampling are given in table 1. More detailed descriptions of the soils and study areas can be found in Alban et al. (1978) and Perala and Alban (1982).

\section{METHODS}

In early September 1972 (loam soil) and 1974 (sand), ten 4- $\mathrm{m}^{2}$ circular understory sampling plots were systematically located in each stand. All herbaceous vegetation was clipped at the ground line to determine biomass and nutrient content (Alban et al. 1978). Herbaceous vegetation was inventoried in this manner because it could not be accounted for in litterfall from the tree and shrub layers.

From August 1, 1974, to August 1, 1976, four $1-\mathrm{m}^{2}$ litter traps were systematically located (in stands of each species) on each soil. Litter collections were made five or seven times a year, concentrating in the autumn during maximum litterfall. For purposes of analysis, samples were composited into two sample periods: August to November, and November to August; but only annual averages are reported here.

Forest floor samples were collected with $930 \mathrm{~cm}^{2}$ metal frames from 40 locations per stand in October 1972 (loam) and July 1974 (sand). To ease the analytical load, forest floor samples were composited in the field to give 10 samples (loam) and 8 samples (sand).
Samples of litter, herbs, and forest floor were ground to pass a 20-mesh screen and were all analyzed in the same manner. Carbon was determined by induction furnace (Allison et al. 1965) and $\mathrm{N}$ by the macro-Kjeldahl method (Bremner 1965). After dry ashing $\left(500^{\circ} \mathrm{C}\right), \mathrm{Ca}, \mathrm{Mg}$, and $\mathrm{K}$ were determined by atomic absorption, and $\mathrm{P}$ by the molybdophosphoric blue colorimetric method (Jackson 1958). Organic matter in herbs and litterfall is simply the ovendry $\left(70^{\circ}\right)$ weight uncorrected for ash; forest floor is corrected for ash.

For the sand, August to November litterfall averages for organic matter, $\mathrm{C}$, and nutrients were added to the forest floor to adjust for differences in forest floor sampling times. Thus the forest floor values represent the period immediately following leaf drop for native deciduous trees. The steady-state exponential decay model of Olson (1963),

$$
k=\frac{\mathrm{L}}{\mathrm{Xss}},
$$

was used to estimate instantaneous fractional loss rates $(k)$ for organic matter, $\mathrm{C}$, and nutrients in forest floor. In this equation, $\mathrm{L}=$ annual litterfall weights and Xss = forest floor weights in the steady-state. Half-lives of organic matter, $\mathrm{C}$, and nutrients in the forest floor were estimated from the $k$ values using the equation

$$
t=\frac{\ln (0.5)}{-k}=\frac{-0.693}{-k}
$$

rewritten from Olson (1963),

$$
\ln \left(\mathrm{X} / \mathrm{X}_{\mathrm{o}}\right)=-k t
$$

where $t=$ time (years), and $\mathrm{X}_{\mathrm{o}}=$ original amount of litter organic matter, $\mathrm{C}$, or nutrients, and $\mathrm{X}=$ amount remaining. 


\section{RESULTS}

Depending on species, annual litterfall weights averaged from 6 to 18 percent less on the sand soil than on the loam (table 2). The stands on both soils had less litterfall the second year (herbs not considered since they were sampled in only 1 year), ranging from 7 percent less for aspen to 31 percent less for jack pine. During the 2 years, the ranking by species in total litterfall and in $\mathrm{C}$ was red pine $>$ jack pine $>$ spruce $>$ aspen for both soils. All nutrients in spruce and red pine litterfall were less on the sand than on the loam, but this varied in aspen and jack pine. In spite of having the least litterfall weight, aspen had the greatest amount of litterfall $\mathrm{P}, \mathrm{K}, \mathrm{Mg}$, and, along with spruce, Ca. Spruce and jack pine litterfall had the most $\mathrm{N}$. Carbon was least on the sand for all species.

Overall, organic matter (OM) and $\mathrm{C}$ in the forest floor were less on the sand than on the loam (table $3)$. Aspen had the least forest floor OM and C on both soils, while the conifers were nearly identical. The forest floor on the sand had only 45 to 72 percent of the nutrients found in the forest floor on the loam. The forest floor nutrient levels varied widely among species.

The half-lives of OM, C, and nutrients were shorter on the sand than the loam except for red pine OM and $C$ (table 4). The order of half lives for OM, C, and nutrients in the aspen forest floor was $\mathrm{N}>\mathrm{Ca}>\mathrm{Mg}>\mathrm{P}>\mathrm{C}>\mathrm{OM}>\mathrm{K}$, whereas in the conifers it was generally $\mathrm{Ca}>\mathrm{N}>\mathrm{Mg}>\mathrm{P}>\mathrm{C}>\mathrm{OM}>\mathrm{K}$. Thus, all nutrients, except $K$, were enriched in the forest floor. The ranking of half-lives among species varied depending on nutrient. Spruce had the longest halflives for $\mathrm{K}, \mathrm{Mg}$, and, along with jack pine, $\mathrm{P}$ and $\mathrm{Ca}$.

Table 2.-Organic matter, $C$, and nutrients in annual litterfall ${ }^{1}$

(In kg/ha)

\begin{tabular}{lcccccccc}
\hline \multicolumn{1}{c}{ Stand } & Soil $^{2}$ & $\begin{array}{c}\text { Organic } \\
\text { matter }\end{array}$ & C & N & P & K & Ca & Mg \\
\hline Aspen & L & 4,382 & 1,972 & 40 & 8.2 & 24 & 81 & 8.7 \\
Spruce & S & 4,105 & 1,888 & 39 & 8.3 & 34 & 64 & 9.2 \\
& L & 5,727 & 2,520 & 54 & 6.9 & 16 & 83 & 4.8 \\
Red pine & S & 5,263 & 2,421 & 41 & 5.1 & 12 & 60 & 4.1 \\
& L & 6,916 & 3,389 & 46 & 4.9 & 19 & 40 & 7.0 \\
Jack pine & S & 5,638 & 2,875 & 37 & 3.7 & 18 & 26 & 5.8 \\
& $L$ & 6,210 & 2,919 & 51 & 4.6 & 17 & 45 & 6.5 \\
& $S$ & 5,607 & 2,467 & 46 & 4.8 & 20 & 31 & 5.8
\end{tabular}

'Mean of two collection years, plus herbs.

${ }^{2} \mathrm{~L}=$ loam, $\mathrm{S}=$ sand.
Table 3.-Organic matter, $C$, and nutrients in forest floor

(In kg/ha)

\begin{tabular}{lcccccccc}
\hline \multicolumn{1}{c}{ Stand } & Soil $^{2}$ & $\begin{array}{c}\text { Organic } \\
\text { matter }\end{array}$ & $\mathbf{C}$ & $\mathbf{N}$ & $\mathbf{P}$ & $\mathbf{K}$ & $\mathbf{C a}$ & $\mathbf{M g}$ \\
\hline Aspen & $\mathrm{L}$ & 26,840 & 13,530 & 667 & 60 & 78 & 1,081 & 89 \\
& $S$ & 22,890 & 11,580 & 467 & 38 & 51 & 586 & 64 \\
Spruce & $L$ & 33,080 & 17,580 & 752 & 61 & 76 & 1,398 & 77 \\
& $S$ & 28,070 & 14,050 & 517 & 42 & 49 & 781 & 48 \\
Red pine & $L$ & 30,290 & 15,800 & 538 & 40 & 62 & 660 & 65 \\
& $S$ & 29,390 & 14,890 & 370 & 26 & 39 & 294 & 43 \\
Jack pine & $L$ & 32,750 & 16,860 & 689 & 51 & 68 & 770 & 81 \\
& $S$ & 27,560 & 13,480 & 486 & 34 & 44 & 391 & 53 \\
\hline
\end{tabular}

$' \mathrm{~L}=$ loam, $S=$ sand.

Aspen had the shortest half-lives for P, K, Ca, and, along with red pine, $\mathrm{Mg}$. Aspen also had the longest half-lives for OM, and, along with spruce, $\mathrm{C}$ and $\mathrm{N}$. Generally, half-lives for jack pine were longer than for red pine.

\section{DISCUSSION}

The half-life estimates given here are suitable for comparing gross differences between species-stands and soils (Swift et al. 1979), but their absolute values are less reliable for a number of reasons. First, the annual variation in litterfall is tremendous. For example, over a 7-year period, Ebermayer (1876, cited by Alway and Zon 1930) observed nearly a threefold range in pine litterfall in Bavaria. Second, there can be large yearly and seasonal variation in forest floor weight and nutrients (Yount 1975). Third, nutrients are added to the forest floor from precipitation, through-fall, stemflow, and $\mathrm{N}$-fixation. Fourth, nutrients are retained on exchange sites or by microbial immobilization, and fifth, nutrients are transfered by roots or hyphae. Clearly, the cycling process is enormously complex (Lousier and Parkinson 1976, Swift et al. 1979, Yount 1975).

Table 4.-Half-lives of organic matter, $C$, and nutrients in forest floor

(In years)

\begin{tabular}{lcccrccrr}
\hline \multicolumn{1}{c}{ Stand } & Soil $^{2}$ & $\begin{array}{c}\text { Organic } \\
\text { matter }\end{array}$ & C & \multicolumn{1}{c}{$\mathbf{N}$} & $\mathbf{P}$ & $\mathbf{K}$ & \multicolumn{1}{c}{ Ca } & Mg \\
\hline Aspen & L & 4.2 & 4.8 & 11.6 & 5.1 & 2.3 & 9.3 & 7.1 \\
& S & 3.9 & 4.3 & 8.3 & 3.2 & 1.0 & 6.3 & 4.8 \\
Spruce & L & 4.0 & 4.8 & 9.7 & 6.1 & 3.3 & 11.7 & 11.1 \\
& S & 3.7 & 4.0 & 8.7 & 5.7 & 2.8 & 9.0 & 8.1 \\
Red pine & L & 3.0 & 3.2 & 8.1 & 5.7 & 2.3 & 11.4 & 6.4 \\
& S & 3.6 & 3.6 & 6.9 & 4.9 & 1.5 & 7.8 & 5.1 \\
Jack pine & L & 3.7 & 4.0 & 9.4 & 7.7 & 2.8 & 11.9 & 8.6 \\
& S & 3.4 & 3.8 & 7.3 & 4.9 & 1.5 & 8.7 & 6.3 \\
\hline
\end{tabular}

${ }^{1} \mathrm{~L}=$ loam, $\mathrm{S}=$ sand. 
Finally, the assumption of steady-state cannot be entirely substantiated, although there is strong supporting evidence. The forest floor weights reported here for red pine differ little from those of Minnesota stands 44 to 94 years old (Alban 1974) or 100 and 250 years old (Alway and Zon 1930). There are similar comparisons for jack pine up to 55 years old (Alway and Zon 1930). Therefore, the steady-state assumption does not seem to introduce serious error.

In spite of these many uncertainties, the results compare favorably with those of similar studies. Carbon in the forest floor and annual litterfall in these stands was comparable to those in forests of the eastern United States (Olson 1963). The overall range of $k$ (.14-.22) is medium-high according to Olson (1963), and again within the range reported for eastern conifers. In this study, the range of litter and forest floor $C$ values among species and soils is as great as the range among other stands growing across the eastern U.S. The half-lives for OM are as expected; they are longer than for tropical forests and somewhat longer than for other temperate forests, but much shorter than for boreal forests (table 5). Half-life for aspen litter was slightly longer than for aspen leaf litter after 30 months in 3-mm-mesh bags in Alberta, Canada (Lousier and Parkinson 1976).
The half-lives of nutrients in the forest floor (table 4) were considerably longer than those in other temperate and especially tropical forests, but not much different from those in boreal forests (table 5). The exception was the half-life of $\mathrm{N}$, which is generally much longer in boreal forests.

Nutrient turnover (except for $\mathrm{K}$ ) lagged behind the turnover of organic matter, a universal observation (Swift et al. 1979). The many reasons for this were mentioned earlier.

Forest floor nutrients on the relatively nutrientpoor sand soil were recycled more rapidly than on the loam. This compensated somewhat for the lower inherent fertility of the sand and forest productivity was comparable to the more fertile loam soil (table 1). Why turnover rates were higher on the sand is not known. Tappeiner and Alm (1975) found rapid forest floor decomposition when understory plants were present, especially in red pine stands. The greater proportion of nutrient-rich and relatively easily decomposed litter contributed by shrubs and herbs on the sand (Perala and Alban 1982) accounts in part for faster mineralization. However, litter from the tree layer is not known to decompose faster when mixed with understory litter.

Table 5.-Literature values for half lives of organic matter and nutrients in forest floor

(In years)

\begin{tabular}{|c|c|c|c|c|c|c|c|}
\hline \multicolumn{8}{|c|}{ TROPICAL FOREST } \\
\hline $\begin{array}{l}\text { Location or } \\
\text { species }\end{array}$ & $\begin{array}{l}\text { Organic } \\
\text { matter }\end{array}$ & N & $\mathbf{P}$ & K & Ca & Mg & Reference \\
\hline $\begin{array}{l}\text { Costa Rica } \\
\text { Ghana } \\
\text { West Indies } \\
\text { Columbia } \\
\text { Florida }\end{array}$ & $\begin{array}{r}0.29 \\
.15 \\
.42 \\
.41 \\
.53\end{array}$ & $\begin{array}{r}- \\
0.15 \\
.55 \\
.59 \\
1.56\end{array}$ & $\begin{array}{l}-\overline{0.21} \\
.63 \\
- \\
-\end{array}$ & $\begin{array}{l}- \\
0.10 \\
.17 \\
- \\
-\end{array}$ & $\begin{array}{l}-\overline{0.15} \\
.19 \\
- \\
-\end{array}$ & $\begin{array}{l}- \\
- \\
-\end{array}$ & $\begin{array}{l}\text { Table 7, } \\
\text { Cole and } \\
\text { Johnson } \\
(1978)\end{array}$ \\
\hline \multicolumn{8}{|c|}{ BOREAL FOREST } \\
\hline $\begin{array}{l}\text { Jack pine } \\
\text { Black spruce } \\
\text { Balsam fir } \\
\text { Aspen }\end{array}$ & $\begin{array}{r}5.1 \\
18.9 \\
9.7 \\
12.3\end{array}$ & $\begin{array}{r}7.5 \\
43.0 \\
17.3 \\
32.6\end{array}$ & $\begin{array}{r}10.0 \\
18.7 \\
8.3\end{array}$ & $\begin{array}{l}1.5 \\
7.5 \\
4.9\end{array}$ & $\begin{array}{l}2.6 \\
4.0 \\
9.7\end{array}$ & $\frac{3.7}{8.3}$ & $\begin{array}{l}\text { Table 6, } \\
\text { Krause et } \\
\text { al. (1978) }\end{array}$ \\
\hline \multicolumn{8}{|c|}{ TEMPERATE FOREST } \\
\hline $\begin{array}{l}\text { White pine } \\
\text { Hardwoods } \\
\text { Red pine } \\
\text { Jack pine (age } 30 \text { ) } \\
\text { Jack pine (age 55) } \\
\text { Red pine-hazel } \\
\text { Paper birch-hazel }\end{array}$ & $\begin{array}{l}2.5 \\
.82 \\
8.4 \\
3.5 \\
7.7 \\
2.2 \\
1.2\end{array}$ & $\begin{array}{r}.86 \\
.32 \\
21.3 \\
7.7 \\
13.0 \\
3.3 \\
2.3\end{array}$ & $\begin{array}{r}5.4 \\
.92 \\
14.8 \\
7.3 \\
11.3 \\
2.9 \\
0.8\end{array}$ & $\begin{array}{r}.20 \\
.23 \\
8.6 \\
6.4 \\
10.0 \\
2.1 \\
0.1\end{array}$ & $\begin{array}{r}3.2 \\
1.2 \\
12.2 \\
5.7 \\
9.7 \\
1.7 \\
1.0\end{array}$ & $\begin{array}{l}1.2 \\
.61 \\
= \\
\overline{1.2} \\
0.5\end{array}$ & $\begin{array}{l}\begin{array}{l}\text { Yount } \\
\text { (1975) }\end{array} \\
\text { Alway \& Zon } \\
(1930) \\
\text { Tappeiner \& } \\
\text { Alm (1975) }\end{array}$ \\
\hline
\end{tabular}




\section{CONCLUSIONS}

This study showed strong indirect effects by tree species and soils on the rate of nutrient turnover in the forest floor. Comparisons with results from other studies indicate that turnover rates of nutrients and organic matter vary widely within the same ecoregion, and even within species. Detailed studies of decomposer organisms and their microenvironment are needed to explain these differences.

\section{LITERATURE CITED}

Alban, David H. Red pine site index in Minnesota as related to soil and foliar nutrients. For. Sci. 20: 261-269; 1974.

Alban, D. H.; Perala, D. A.; Schlaegel, B. E. Biomass and nutrient distribution in aspen, pine, and spruce stands on the same soil type in Minnesota. Can. J. For. Res. 8: 290-299; 1978.

Allison, L. E.; Bollen, W. B.; Moodie, C. D. Total carbon. In: Black, C. A., ed. Methods of soil analysis. Agron. 9: 1346-1366; 1965.

Alway, F. J.; Zon, Raphael. Quantity and nutrient contents of pine leaf litter. J. For. 28: 715-727; 1930.

Bailey, Robert G. Description of the ecoregions of the United States. Misc. Pub. 1391. Washington, DC: U.S. Department of Agriculture, Forest Service; 1980. 77 p., plus map:

Bremner, J. M. Total nitrogen: regular macro-Kjeldahl method. In: Black, C. A., ed. Methods of plant analysis. Part 2. Agron. 9: 1162-1164; 1965.

Cole, D. W.; Johnson, D. W. Mineral cycling in tropical forests. In: Youngberg, C. T., ed. Forest soils and land use. Ft. Collins, CO: Department Forest and Wood Science, CO State University; 1978: 341356.

Ebermayer, E. Die gesammte Lehre der Waldstreu. Berlin; 1876. 300 p. (In German; original not read).

Jackson, M. L. Soil chemical analysis. Englewood Cliffs: Prentice-Hall, Inc.; 1958. 498 p.

Krause, H. H.; Weetman, G. F.; Arp. P. A. Nutrient cycling in borealforest ecosystems of North America. In: Youngberg, C. T., ed. Forest soils and land use. Ft. Collins, CO: Department Forest and Wood Science, CO StateUniversity; 1978: 287-319.

Lousier, J. D.; Parkinson, D. Litter decomposition in a cool temperate deciduous forest. Can. J. Bot. 54: 419-436; 1976.

Olson, J. S. Energy storage and the balance of producers and decomposers in ecological systems. Ecology 44: 322-331; 1963.

Perala, D. A.; Alban, D. H. Biomass, nutrient distribution and litterfall in Populus, Pinus, and Picea stands on two different soils in Minnesota. Plant and Soil 64: 177-192; 1982

Swift, M. J.; Heal, O. W.; Anderson, J. M. Decomposition in terrestrial ecosystems. Berkeley, CA: University of California Press; 1979. $372 \mathrm{p}$.

Tappeiner, J. C.; Alm, A. A. Undergrowth vegetation effects on the nutrient content of litterfall and soils in red pine and birch stands in northern Minnesota. Ecology 56: 1193-1200; 1975.

Yount, J. D. Forest floor nutrient dynamics in southern Appalachian hardwood and white pine plantation ecosystems. In: Howell, F. G.; Gentry, J. B.; and Smith, M. H., eds. Mineral cycling in Southeastern ecosystems. Springfield, VA: National Technical Information Service, U.S. Department Commerce, U.S. Energy Research and Development Administration. 1975: 598-608. 
Perala, D. A.; Alban, D. H.

Rates of forest floor decomposition and nutrient turnover in aspen, pine, and spruce stands on two soils. Res. Pap. NC-227. St. Paul, MN: U.S. Department of Agriculture, Forest Service, North Central Forest Experiment Station; 1982. 5 p.

Compares rates of forest floor decomposition and nutrient turnover in aspen and conifers. These rates were generally most rapid under aspen, slowest under spruce, and more rapid on a loamy fine sand than on a very fine sandy loam. Compares results with literature values.

KEY WORDS: Mineralization, nutrient cycling, litterfall, nitrogen, phosphorus, potassium, calcium, magnesium. 